\title{
Adaptation to a landscape-scale mountain pine beetle epidemic in the era of networked governance: the enduring importance of bureaucratic institutions
}

\author{
Jesse B. Abrams $^{1}, \underline{\text { Heidi R. Huber-Stearns }}^{1}$, Christopher Bone $^{2}$, Christine A. Grummon $^{3}$ and Cassandra Moseley $^{1}$
}

\begin{abstract}
Landscape-scale forest disturbance events have become increasingly common worldwide under the combined influences of climate change and ecosystem modification. The mountain pine beetle (Dendroctonus ponderosae) epidemic that swept through North American forests from the late 1990s through the early 2010s was one of the largest such disturbance events on record and triggered shocks to ecological and economic systems. We analyze the policy and governance responses to this event by focusing on three national forests in the state of Colorado and on the agency responsible for their management, the U.S. Forest Service. We found that the event triggered the formation of new hybrid agency/nonagency organizations that contributed both legitimacy and capacity to address the most immediate threats to human safety and infrastructure. Despite the use of a highly networked governance structure, longstanding U.S. Forest Service institutions continued to heavily influence the scope of the response and the means for implementing management activities. We detected relatively limited institutional response at the level of the agency as a whole, even as regional- and local-scale institutions within Colorado showed greater dynamism. Indeed, the changes to agency institutions that were detected were largely consistent with institutional change trajectories already in place prior to the epidemic. Our study points to the importance of institutional persistence and path dependence in limiting the latitude for adaptation to social and environmental shocks.
\end{abstract}

Key Words: adaptive capacity; bark beetle; bureaucracy; institutional change; U.S. Forest Service

\section{INTRODUCTION}

Complex intersections of ecosystem modification, climate change, and socio-political dynamics have triggered widespread and, in some cases, irreversible shocks to linked social-ecological systems (SES) worldwide, including forested systems that are valued for their diverse natural and cultural benefits (Flint et al. 2009, Mueller 2011, Wyborn et al. 2015, Morris et al. 2017). A key concern of researchers and practitioners in the field of SES dynamics has been to understand the mechanisms by which the structures and processes of SES governance, composed of multiple interacting social and political actors, organizations, and institutions at various scales, are able to adapt in anticipation of, or in response to, extreme events such as floods, droughts, and uncharacteristically severe wildfires (Birkmann et al. 2010, Paton and Tedim 2012). The adaptive governance literature emphasizes institutions, the relatively persistent formal and informal rules and guidelines of social behavior (North 1990, Ostrom 1990, 2005, Young 2002a, Scott 2014), as key considerations for understanding how the responses of people and organizations to environmental change are structured (Folke et al. 2005, Djalante et al. 2011, Chaffin et al. 2014). A greater understanding of the institutional factors shaping social and political responses to environmental extremes promises to contribute to improved policy and practice for supporting social-ecological systems under the myriad pressures associated with global change.

Prior research on the institutional dimensions of SES dynamics has explored a variety of institutional drivers at multiple scales (Berkes et al. 1998, 2003, Cumming et al. 2013), but explicit consideration of the institutions and governance networks associated with land management bureaucracies has been relatively underdeveloped. This is the case despite the fact that these bureaucracies often exercise substantial control over natural resource decision making. For example, the U.S. Forest Service
(USFS) is charged with the management of 78 million hectares of forestlands and other habitats across the U.S., including landscapes that have been the sites of extreme events related to insects, wildfires, and other factors. The present study contributes to a burgeoning literature on the governance of environmental extremes through an analysis of the social and political responses to a landscape-scale outbreak of the native mountain pine beetle (MPB; Dendroctonus ponderosae) in the state of Colorado, USA. The state of Colorado was arguably the most heavily affected U. S. state in a forest insect epidemic of unprecedented scale that stretched from Mexico to northern Canada and resulted in forest dieback across millions of hectares during the first decade of the twenty-first century (Mitton and Ferrenberg 2012, Petersen and Stuart 2014). We analyze how the long-term institutional evolution of the USFS (the agency responsible for managing the majority of beetle-affected forests in Colorado and the broader U.S. West) intersected with local- and regional-scale actions to shape the managerial, organizational, and institutional response to this epidemic.

\section{ENVIRONMENTAL GOVERNANCE AND EXTREME EVENTS}

The body of literature broadly associated with SES resilience has long placed emphasis on institutions as key determinants of social-ecological relationships (Ostrom 1990, Berkes et al. 2003, Folke et al. 2005, Lebel et al. 2006, Young 2010). The concept of adaptive governance refers to an institutional design characterized by relationships between and among individuals, organizations, management agencies, and other key entities at various scales that encourage adaptive learning and institutional reform (Garmestani and Benson 2013, Chaffin et al. 2014, Bettini et al. 2015, Koontz et al. 2015). Adaptive capacity reflects the ability of people within specific institutional settings to

${ }^{1}$ Ecosystem Workforce Program, Institute for a Sustainable Environment, University of Oregon, ${ }^{2}$ Department of Geography, University of Victoria, ${ }^{3}$ Department of Geography, University of Oregon 
proactively or reactively respond to threats and dynamics (Smit and Wandel 2006), with adaptation associated with greater flexibility of institutions, opportunities for communication and learning, a polycentric design that avoids high transaction costs, and the presence of leadership in the face of complex challenges (Koontz et al. 2015).

The emergence of a network governance approach, in which organizations and institutions operating at multiple scales link to one another through formal or informal networks, is believed to be an effective model for adaptive governance of complex, largescale dilemmas (Alexander et al. 2016, Scarlett and McKinney 2016). The network paradigm is typically conceived as an alternative to both hierarchical (state-led) and market-based models, with its strength deriving from its flexibility, its basis in trust and reciprocity, and its ability to address complex multiscalar issues (Keast et al. 2006). Network governance is closely related to concepts such as collaborative and place-based governance, but is specifically characterized by the coordination of actors and entities operating at different scales via formal and informal network linkages (Newig et al. 2010, Scarlett and McKinney 2016)

Questions of institutional adaptability are paramount in analyses of centralized bureaucracies, which are often characterized as maladaptive (Holling and Meffe 1996, Shinn 2016). Contributions to Gunderson et al. (1995), for example, analyze multiple instances in which large-scale bureaucracies worked to reduce the natural variability in systems, only to generate largerscale crises that escaped the rational control typical of bureaucratic environmental management. Many SES resilience researchers have concluded that devolved or decentralized institutional designs are likely to be more adaptive than rigid centralized arrangements (Ostrom 1990, Young 2002b, Basurto 2005, Berkes 2012, Koontz et al. 2015). However, devolution by itself is no panacea (Ostrom 2001); among other things, local organizations must contend with the same questions of legitimacy that often plague centralized approaches (Cosens 2013) and with limited access to higher-scale data and formal knowledge (Klooster 2002). Further, specific institutional design elements and path dependencies can affect the ultimate success of devolved and decentralized governance approaches (Bartley et al. 2008, Dressler et al. 2010). Broad interests in designing more adaptive institutional arrangements are complicated by the knowledge that institutions often evolve in complex ways, often over long time periods, rather than being intelligently designed from the outset to serve specific purposes (Cleaver 2002, Streeck and Thelen 2005, Dowsley 2008, Mahoney and Thelen 2010). Among other things, this means that hierarchical, market-based, and networked governance models may be combined in various ways in practice, and the presence of network structures does not necessarily imply the absence of hierarchical elements (Keast et al. 2006).

Concerns with institutional adaptability have become particularly important in light of recent landscape-scale disturbances that challenge ideals of bureaucratic control. A great deal of political science scholarship has investigated the dynamics of institutional and organizational change following "focusing events," sudden and spatially contained events that are generally evaluated as harmful and are known to policymakers and the public simultaneously (Birkland 2006). Although these events may help to open a "policy window" in which institutional reform may occur, this is no guarantee that adaptive change will follow (Solecki and Michaels 1994, Birkland 2006, Boin et al. 2008, Nohrstedt and Weible 2010, Plummer et al. 2010). Prior scholarship on social and political responses to environmental extremes has documented instances in which a major environmental event (such as a flood, wildfire, or hurricane) has triggered social reorganization and institutional reform, in some cases leading to better preparation for future environmental variability (Solecki and Michaels 1994, Birkmann et al. 2010, Armitage et al. 2011), as well as numerous instances in which crises resulted in little or no lasting change (Naess et al. 2005, Nelson 2007, Abrams et al. 2015a, Mockrin et al. 2016) or in maladaptive change (Shinn 2016).

Forest insect epidemics exemplify complex environmental change events that challenge bureaucratic control and at least potentially open windows of opportunity for adaptation. Nelson (2007) demonstrated that the ecological and economic crisis of the most recent MPB outbreak in British Columbia led to relatively little formal policy change, despite the scale of the disaster and the centrality of the wood products industry to the provincial economy. Indeed, the contours of the response to this crisis were strongly shaped by the interests of the timber industry, which had gained substantial independence from the provincial forestry authority following a series of neoliberal reforms (Petersen and Stuart 2014). However, the epidemic did trigger the organization of Beetle Action Coalitions, regional-scale multistakeholder entities financed by the provincial government to plan for response and recovery. Davis and Reed (2013) observed that the Cariboo-Chilcotin Beetle Action Coalition drew heavily upon both prior experiences with network governance and particular community and regional identities in crafting its response. A western pine beetle (Dendroctonus brevicomis) epidemic in Southern California, an area in which forests are valued more for their recreational value than for timber production, also catalyzed new governance relationships at the regional scale that led to an influx of public funds and catalyzed the creation of a coordinated management plan focused on areas of critical human infrastructure (Petersen and Wellstead 2014). At the same time, Wyborn et al. (2015) detailed the lack of local trust in the USFS and its decision-making procedures in the wake of the MPB outbreak in Grand County, Colorado, concluding that the community is likely to remain reactive and incremental rather than proactive and transformative in the face of future climatedriven environmental dynamics.

These cases suggest that event-triggered institutional change may occur through the emergence of new networks of planning and practice at regional to local scales even as national policies, procedures, and cultures continue relatively unchanged. However, given the institutional complexity of large bureaucracies like the USFS, it remains unclear how individual events affect longer-term trajectories of institutional evolution (Beier et al. 2009). We address this gap by analyzing the ca. 2000-2010 North American MPB outbreak, paying particular attention to how this event altered, if at all, the preexisting institutional trajectory associated with USFS management of public forestlands in northwestern Colorado. 


\section{THE U.S. FOREST SERVICE, DISTURBANCES, AND INSTITUTIONS}

As of 2017, the USFS manages 154 national forests and 20 national grasslands within the National Forest System. These lands are disproportionately concentrated in the eleven western states plus Alaska and represent more than half of all timberland acreage in these states (Smith et al. 2009). The agency has a "multiple use" mandate to provide for a blend of consumptive (e.g., timber, livestock forage) and nonconsumptive (e.g., outdoor recreation, wildlife conservation) uses. As an agency, the USFS is characterized by both centralization and decentralization; overall policy and legal obligations are set through policymaking at the national level (i.e., federal legislation and administrative rule making), but managerial decisions are made by local district rangers, forest supervisors, and regional foresters acting within a system of targets and allocated resources determined at higher levels of the bureaucracy.

The overall decision-making paradigm within the agency has shifted over time, chiefly representing three broad phases: (1) in the early twentieth century following the establishment of the USFS, rangers were expected to make independent decisions insulated from outside pressures under a broadly defined "greatest good" philosophy (Kaufman 1960, Wilson 2014); (2) following a spate of federal legislation in the 1970s, forest managers began working under a rational planning paradigm that assumed that extensive analysis of possible impacts of managerial decisions, combined with structured opportunities for public input, would help resolve rising public discord regarding the tensions between consumptive and nonconsumptive activities (Le Master 1984, Beier et al. 2009); (3) in the wake of a series of social and political crises regarding endangered species conservation on federal forestlands in the 1990s, which moved USFS management away from its traditional emphasis on timber production, there has been an uneven movement toward "social forestry" (Winkel 2014), in which the agency increasingly depends on the legitimacy and capacity contributions of outside entities to make and implement decisions (Cheng et al. 2011, Winkel 2014, Abrams et al. 2015b).

This most recent phase is itself the outcome of multiple socialecological drivers, including a reorientation of USFS management toward forest health concerns (e.g., wildfires, insect and disease outbreaks), the shifting of resources from core forest management duties to wildfire suppression (Steelman and Burke 2007), and an institutional setting characterized by Fukuyama (2014) as a "vetocracy," in which a proliferation of veto players (e.g., other federal agencies, the concerned public, the courts) complicates a bureaucracy's ability to efficiently make and implement decisions (Wyborn et al. 2015). It reflects as well a larger trend of the neoliberalization of federal forest management, characterized by reduced public investments and greater reliance on private and civil society contributions (McCarthy 2005). The networked governance approach typical of the social forestry phase can thus be seen as an emergent response to both broad institutional pressures and specific ecological shocks such as the ca. 2000-2010 MPB outbreak.

The Colorado MPB epidemic of ca. 2000-2010 had roots in a complex of long-term drivers that include: (1) a series of fires and timber harvests throughout the twentieth century that created large, contiguous patches of mature, beetle-susceptible lodgepole pine (Pinus contorta) stands; (2) the natural history of lodgepole pine, a species that often grows in even-aged stands, which are eventually "reset" by stand-replacing fire or insect outbreaks; (3) climate variables that led to droughts, higher summer temperatures, and warmer winters, all of which facilitate the flipping of MPB populations from endemic to epidemic levels (Raffa et al. 2008); (4) past MPB control efforts on the part of the USFS, such as those implemented during outbreaks in the midtwentieth century and early 1980s (Furniss 2007, Andrews 2011). Against the backdrop of these long-term drivers, the 2000-2010 outbreak in northwest Colorado formed one particularly active epicenter of a continental-scale MPB outbreak that outpaced any prior native forest epidemic in North American history (Mitton and Ferrenberg 2012, Petersen and Stuart 2014). The state of Colorado estimates that over 1.3 million hectares statewide were affected by the MPB (CSFS 2017; Fig. 1). The heaviest mortality occurred in lodgepole pine forests on the Arapaho-Roosevelt National Forest (ARNF), Medicine BowRoutt National Forest (MBRNF), and White River National Forest (WRNF; Fig. 2).

Fig. 1. Area of forests affected by mountain pine beetle in the state of Colorado, 1997-2014. Data from U.S. Forest Service, Aerial Detection Survey.

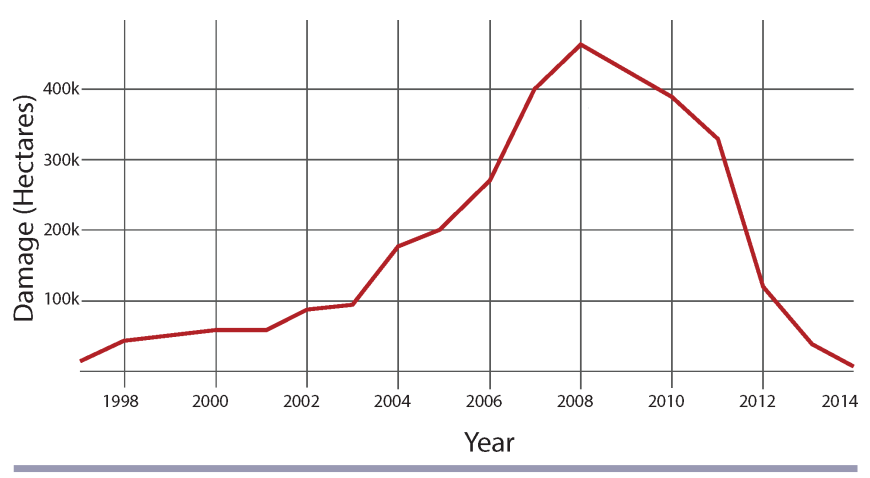

Colorado had experienced prior epidemics of MPB and other forest insects, with prominent events occurring around the turn of the twentieth century, in the 1920s, the 1940s, and the 1970s through the early 1980s (Andrews 2011). However, the ca. 2000-2010 MPB epidemic outpaced all of these prior events in scale and scope. It was highly visible to both local residents and visitors, particularly during the "red needle" phase in which whole mountainsides appeared to be dying. Given Colorado's heavy reliance on tourism, outdoor recreation, and rural real estate, there was widespread concern about impacts on local and regional economies. The security of people and infrastructure was a particular concern, given that beetle-killed trees were at risk of falling on powerlines, homes, and people, and also of blocking roads and trails. Additionally, during the period of the epidemic, Colorado experienced a series of destructive wildfires, generating public concern about possible heightened fire risks associated with the proliferation of beetle-killed trees. These dynamics took place within a context of a USFS presence in Colorado that had, since the 1980s, transitioned away from a timber emphasis to a recreation emphasis and was increasingly tasked with protecting municipal water supplies and developed areas from fire risk. 
Fig. 2. Location of Arapaho-Roosevelt National Forest, Medicine Bow-Routt National Forest, and White River National Forest in Colorado, USA. Spatial extent of mountain pine beetle damage, 1997-2014. Beetle data from U.S. Forest Service, Aerial Detection Survey. MPB = mountain pine beetle.

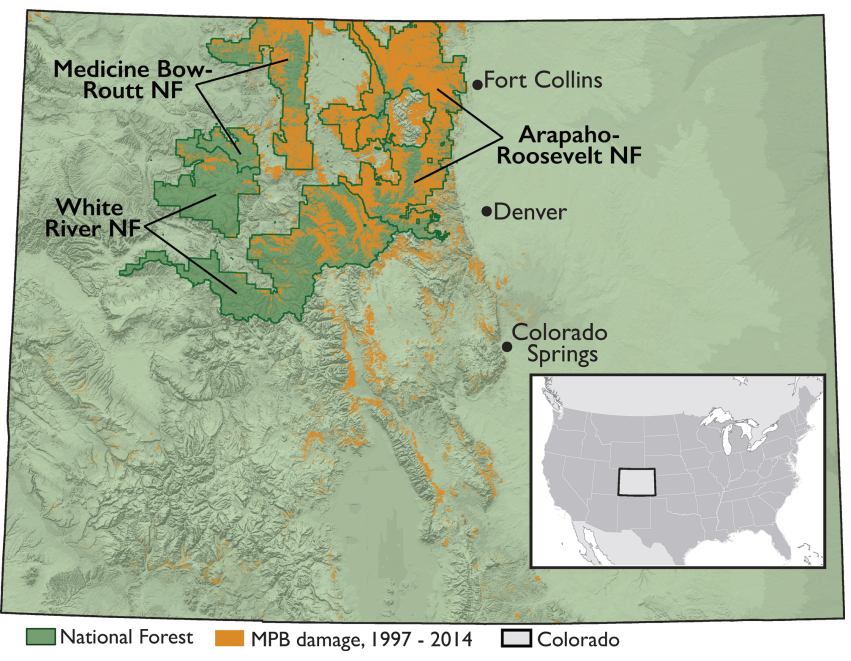

Thus, the response of various network actors to the MPB epidemic in Colorado provides an opportunity to examine the adaptability of institutions at multiple scales. We pay particular attention to the relationships between national, regional, and local scales of action and the adaptation (or lack thereof) of institutions that resulted from this ecological, economic, and social shock.

\section{METHODS}

We used a case-study approach (Yin 2003, Flyvbjerg 2006) to investigate institutional responses to the ca. 2000-2010 MPB outbreak in northwestern Colorado. Because this area was the most heavily affected by the epidemic, combined with the fact that Colorado interests were well-represented in national policymaking circles at the time, this can be considered a "critical case" (Flyvbjerg 2006) for investigating the adaptability of forest governance institutions; meaning that if institutional adaptation were not detected here, it would be unlikely to occur elsewhere. We conducted data collection primarily through key-informant interviews using a semistructured interview protocol, focusing on individuals both inside and outside the USFS who were involved in issues of governance, decision making, and management of the epidemic and its aftermath. These included representatives of the USFS at regional (Region 2), individual national forest, and ranger district scales (11 interviewees), Colorado State Forest Service (4), environmental and place-based NGOs (7), and of other entities such as the National Park Service, wood products businesses, county/local governments, and water and power utilities (7). Potential interviewees were identified initially through contacts from prior research in the region and expanded via snowball sampling. Twenty-nine semistructured interviews were conducted in 2016-2017; 22 were conducted in person and the remaining 7 by telephone or Skype. Most interviews were audiorecorded with the permission of the interviewee and later transcribed verbatim; otherwise, extensive notes were taken during the interview.

We complemented these interview data with secondary data gathered from other sources. Broadly, these consisted of three types: (1) USFS timber sale data from 1996 to 2016, systematically collected from annual "cut and sold" reporting documents and used to track timber management activity over time; (2) quarterly steering committee meeting minutes from the Colorado Bark Beetle Cooperative (CBBC) from November 2007 to November 2015, used to track participation in a leading collaborative governance organization over time; (3) other documents and data, including online databases of USFS management activities, news reports of MPB-related issues, organizational websites, and reports collected opportunistically from interviewees or via web research, used to triangulate or cross-verify findings from our qualitative interviews. This last category of documents primarily represented information corresponding to the time period of the MPB epidemic under study (from the late 1990s through 2017). Unless otherwise indicated, research findings came from interview transcripts cross verified by secondary sources.

Our interview transcripts were reviewed multiple times with the use of NVivo 11 qualitative analysis software to generate themes through an iterative process of coding (Strauss and Corbin 1998). We used these transcripts and themes, together with the secondary data noted above, to build a "chain of evidence" (Yin 2003) for the construction of a credible narrative of events. To discern whether or not adaptation occurred, we specifically searched for changes made in response to the MPB epidemic and its impacts that appeared to have at least the possibility of becoming institutionalized. Changes that represented short-term deviations from the status quo ante were not considered to be examples of adaptation, but changes that appeared to persist past the immediate emergency response period were. Our study has the benefit of a relatively long time period between event and research; the MPB epidemic on which we focus began in the late 1990s and had largely run its course by 2011 (for simplicity's sake, we refer to the epidemic as having lasted from 2000-2010). Our fieldwork in 2016-2017 thus represents a perspective from several years out, minimizing the possibility that we had missed a delayed response in the form of new policies or programs (Birkland 2006).

\section{RESULTS}

\section{Responding under vetocracy}

The MPB outbreak generated widespread anxiety at the local scale, resulting in public pressure on the USFS to respond. Many of our interviewees, both inside and outside the USFS, described a situation in which a northwest Colorado public, which had long favored a largely hands off approach to federal forest management, suddenly began to demand more aggressive managerial intervention in the face of the MPB epidemic. Nearly all interviewees made some kind of reference to a change in "social license" (i.e., public acceptance of active forest management by the USFS) in favor of more aggressive management during the epidemic, though not all interviewees explicitly used that term. The combined agency and nonagency response to the outbreak included a mix of local- to regional-scale actions, such as the creation of new organizations and initiatives at local or state levels, and national-scale actions, largely centered around attempts to 
Table 1. Principal policy and practice changes related to the ca. 2000-2010 mountain pine beetle (MPB) epidemic in northwest Colorado that emerged through interviews and document review. USFS = U.S. Forest Service; NEPA = National Environmental Policy Act; ARNF = Arapaho-Roosevelt National Forest; WRNF = White River National Forest; MBRNF = Medicine Bow-Routt National Forest.

\begin{tabular}{|c|c|c|c|}
\hline MPB-related change & Scale & Purpose & Persistence after end of epidemi \\
\hline $\begin{array}{l}\text { Founding of local collaborative } \\
\text { groups: Future Forests Roundtable, } \\
\text { Summit County Forest Health Task } \\
\text { Force, For the Forest }\end{array}$ & Local (community to county) & $\begin{array}{l}\text { Build community agreement on } \\
\text { actions; conduct outreach and } \\
\text { education; generate funding for } \\
\text { treatments }\end{array}$ & $\begin{array}{l}\text { Groups continued to exist as of } \\
\text { 2017, but with new focus (less } \\
\text { emphasis on MPB) }\end{array}$ \\
\hline $\begin{array}{l}\text { USFS use of new contracting, } \\
\text { budgeting, and implementation } \\
\text { procedures: stewardship } \\
\text { contracting, Good Neighbor } \\
\text { Authority, payments by }\end{array}$ & $\begin{array}{l}\text { Local (individual national forests } \\
\text { and ranger districts) }\end{array}$ & $\begin{array}{l}\text { Support investments in wood } \\
\text { processing infrastructure through } \\
\text { predictable supply of material; } \\
\text { leverage new sources of funding and } \\
\text { implementation capacity }\end{array}$ & $\begin{array}{l}\text { Stewardship contracts continue } \\
\text { through 2022; use of other } \\
\text { authorities continued following } \\
\text { MPB epidemic }\end{array}$ \\
\hline
\end{tabular}

communities and utilities, NEPA

planning at larger scales

USFS use of Incident Command Regional (three national forests) structure to oversee MPB treatments

Founding of Colorado Bark Beetle Cooperative (since renamed High Country Forest Collaborative)

Colorado forest health legislation

Dedication of federal funds to ARNF, WRNF, MBRNF

Expansion/reauthorization of

National Stewardship Contracting and Good Neighbor Authority; inclusion of insect emergency provisions in 2014 Farm Bill Regional (state)

Regional (multicounty)

Regrate)

National funding, local application Maximize efficiency in planning a
implementation, demonstrate
accountability in spending money

Generate agreement on actions; advocate for dedicated funding; advocate for policy changes; conduct outreach and education

Encourage forest management and wood utilization through tax deductions, grants, and other incentives and changes to state law (ca. 25 laws in total)

\section{Pay for planning and} implementation of hazard mitigation projects near homes and critical infrastructure

Provides additional tools to federal forest managers (Stewardship Contracting, Good Neighbor) and to states (Good Neighbor, Farm Bill) to conduct management on federal forestlands
The Incident Command structure continued to exist but is not generally used in forest treatment planning and implementation

Continued to exist as of 2017, but with focus on regional convening, coordination, education, and outreach (less emphasis on MPB)

As of 2017, many laws continue in effect; some programs that require funding have not been renewed

One-time pulse of funding, no longterm change

As of 2017, these policies continue in effect (note: the link between the MPB epidemic and these changes is not well established) direct greater financial resources and managerial flexibility to affected USFS units (Table 1). At a local level, USFS units prioritized their immediate management response on high-use recreational areas such as campgrounds, attempting to protect individual trees through the application of insecticides. Across the broader landscape, the agency was limited early on in its ability to respond by the nature of the project planning process and limited financial resources for planning and implementation. Interviewees described the scale of the epidemic quickly outpacing the ability of the USFS to plan or implement any kind of effective managerial response.

The most important organizational player in facilitating USFS action in response to the MPB was the Colorado Bark Beetle Cooperative (CBBC). The group formed initially in 2005 as a project of the Northwest Colorado Council of Governments, which represents local and county governments in five northern Colorado counties, four of them highly economically dependent on tourism and outdoor recreation. The impetus for the group came from a combination of concern on the part of local governmental officials and regional USFS leaders who recognized the need for a civil society organization to advocate for state and federal attention to the issue. In its early form, the group included a steering committee of the forest supervisors of the ARNF, MBRNF, and WRNF, the Colorado State Forester, county commissioners from six affected counties, and mayors or council members from multiple communities.

In 2007-2008, the CBBC expanded to include participation from water and power utilities concerned about potential MPB impacts on their operations, as well as representatives of conservation organizations, wood products firms, and other nongovernmental 
Fig. 3. Participation, by interest or agency represented, in steering committee meetings of the Colorado Bark Beetle Cooperative, November 2007-November 2015. Data from CBBC meeting minutes.

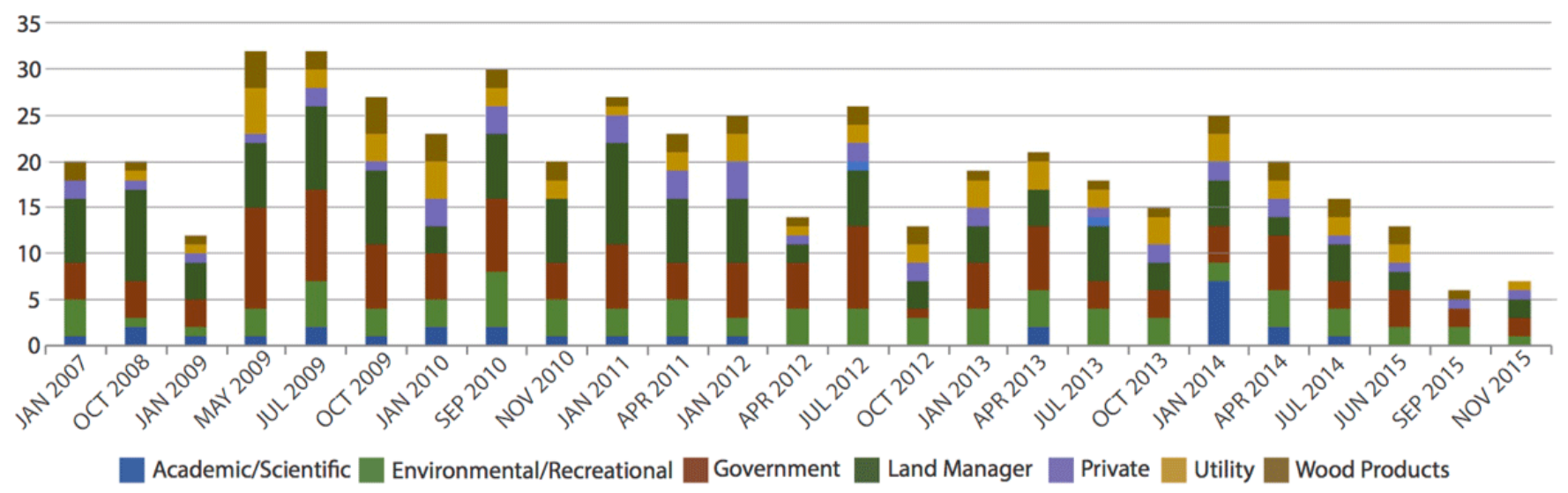

entities; four additional counties also joined the cooperative at this time. These changes were made, in part, to increase the group's legitimacy in political arenas. It was at this point that the cooperative transitioned from a multigovernmental organization to a multistakeholder collaborative organization and brought in experts on collaborative process from Colorado State University to help facilitate decisions on issues such as membership, decisionmaking processes, rules of operation, and structure. The CBBC would go on to play a leading role in both establishing the kinds of forest management activities that would be acceptable and in organizing to fund the implementation of those activities. According to our analysis of meeting minutes, representatives of some 70 distinct organizations attended CBBC meetings between 2005 and 2015 (Fig. 3; Grummon 2016).

The CBBC's substantive deliberations focused on values for prioritizing response and actions needed to realize those values. According to interviewees, early conversations among the diverse stakeholders assembled as part of the CBBC were not very productive because they largely recapitulated longstanding conflicts regarding the extent to which the USFS should aggressively manage forests and the prudence of intervening in potentially natural events such as MPB epidemics. The group was ultimately able to reach consensus on a "zone of agreement" once the ecological and political limitations of the landscape became clear:

\section{We actually did an analysis. Out of Summit County... you take out wilderness, you take out above timberline. When you took out all those areas, the steep slopes and roadless and all that kind of stuff, highways, roads, you name it, there was only about ten percent of the entire land mass in the entire county that could actually be treated (Interview \#15).}

With these limitations in mind, the group quickly moved from conflict to broad agreement on the need to prioritize immediate human health, safety, and infrastructure needs in the face of potential threats posed by the post-MPB landscape. Documents show that the three values initially identified by the CBBC were:
1. Protection of human life and property;

2. Protection of vital public and private infrastructure; and

3. Protection of critical sources of water supply.

The five actions identified to protect these values were:

1. Clear administrative and regulatory barriers that prevent work from being done;

2. Influence state and federal legislation, including budgets and funding;

3. Build social acceptance by conducting public education and outreach about the causes of forest mortality and the necessary management actions;

4. Lower the cost of forest treatments by developing privatesector businesses capable of adding value to removed woody material; and

5. Conduct mitigation and emergency preparedness to reduce threats to life, property, infrastructure, and water supplies.

According to interviewees, the kinds of forest management activities that were envisioned by $\mathrm{CBBC}$ members were largely the removal of hazardous trees from high-traffic areas such as campgrounds, hiking trails, and access roads, as well as from populated areas and infrastructure corridors in which falling trees could endanger human safety or infrastructure. Many interviewees felt that the political strength of $\mathrm{CBBC}$ came from the fact that a diverse assortment of stakeholders was advocating for a common solution the problem, and that the organization was able to stay "on message" in its conversations with higherlevel political actors.

The CBBC's emphasis on navigating the challenges of a vetocratic institutional setting can be seen both in its overall focus on establishing a zone of agreement and in the five actions identified by the group. Specific examples of "clearing administrative and regulatory barriers" achieved by the CBBC were noted by interviewees. These included removing the requirement that ski resort owners pay a fee to the USFS to remove dead trees from 
their ski areas and using the federal Good Neighbor Authority (a recently passed law allowing non-USFS partners to implement projects on federal forestland) to allow state foresters to do work along federal-private property boundaries where physical access issues were controversial. In another case, a mill seen as a key economic support for tree removal was burdened by the fact that it had purchased a timber sale at green tree rates only to see the trees die from MPB attack before they were harvested. The CBBC worked with the Colorado congressional delegation to reclassify the sale as a salvage sale, thereby returning money to the mill that otherwise would have been lost on low-value timber. The CBBC's national-level political work was facilitated by the status of Colorado elected officials in positions of power within the congressional structure, as well as by the appointment of a former Colorado senator to the position of Interior Secretary in 2009. In parallel with the CBBC, other local-scale groups (e.g., Future Forests Roundtable and For the Forest, both in the Aspen, Colorado area, and Summit County Forest Health Task Force) emerged to provide community outreach and education and to mediate between communities and nearby USFS units, in many cases getting involved in the kinds of project-level deliberations that were too "fine grained" for the CBBC.

\section{Building from diminished capacity}

Establishing a zone of agreement and working to reduce the administrative friction caused by various USFS planning and contracting rules represented one major element of the CBBC's activities; the other major element was concerned with finding ways to fund the extensive work that would be required to plan and implement treatments across large swaths of high-priority forestland. According to interviewees (and consistent with the data presented in Figure 4), the USFS in Colorado had, since the 1990s, largely tapered down its capacity for planning and administering timber sales, focusing instead on recreation and fire suppression amid declining national budgets for nonfire staffing:

[Colorado USFS units] went through a long phase where everything was recreation driven. They hardly had a timber staff. They didn't have a lot of depth on their bench to deal with [the MPB outbreak], and they had developed a culture over a twenty-plus year period of not harvesting... and so it was very difficult for them to change directions (Interview \#4).

The low level of timber harvest activity on federal forests and the declining timber processing infrastructure in the state created a path dependency that left the state with few avenues for adding value to trees of any size or condition that were targeted for removal in the face of the MPB epidemic. This, combined with the marginal market value of beetle-killed lodgepole pine, meant that the agency often had to pay for tree removal rather than being able to sell the trees that it wanted removed. According to interviewees, these costs regularly exceeded $\$ 3700$ per hectare in beetle-affected areas.

The CBBC worked at both state and federal levels in its attempts to bring substantial financial resources back to local forests for project planning and implementation. It had the greatest success at the federal level and it secured a total of approximately US\$55 million through a variety of channels, most importantly via the reallocation of existing monies from across the Rocky Mountain Region and the USFS as a whole. Funds directed to the three national forests for MPB response were used to hire planners who could complete required environmental analyses on proposed projects and administrators to conduct project layout and oversight, and were also used to pay for implementation of treatments through timber sales (Fig. 4), stewardship contracts, and service contracts. Timber sale contracts were used when the value of the product removed was greater than the costs to harvest and haul it; otherwise the USFS used service or stewardship contract arrangements in which it paid for private contractors to conduct activities such as hazard tree removal from around critical infrastructure.

Fig. 4. Volume of sawtimber, fuelwood, and other timber harvested on the Arapaho-Roosevelt, Medicine Bow-Routt, and White River National Forests (combined), 1996-2016. Data from U.S. Forest Service annual cut and sold reports.

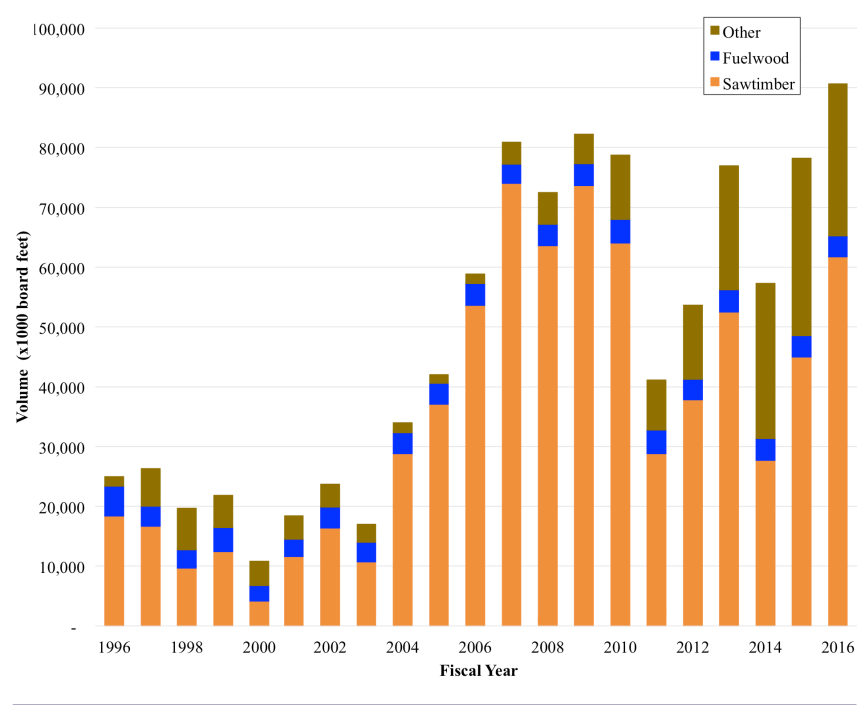

Interviews revealed that, despite the influx of federal funding, the USFS still struggled to respond quickly given the scale of the work to be done and the limited pre-existing USFS capacity. The agency compensated in part through the use of novel planning, contracting, and funding procedures in which nonfederal entities helped to fill in for missing capacity. For example, USFS units created agreements with utilities, such as water and power providers, in which the utility would pay all or a substantial proportion of treatment costs on critical federal lands (e.g., watersheds that served municipal supplies or forests near power infrastructure). Power utilities were concerned about both tree fall and fire risk, whereas water utilities were concerned about the loss of soil stabilization functions provided by living trees. In another case, a high-income neighborhood whose residents had traditionally opposed timber management projects contributed funding for MPB mitigation work on neighboring USFS land.

The USFS also took advantage of authorities derived from prior administrative and legal changes associated with the Healthy Forests Initiative and Healthy Forests Restoration Act of 2003 that allowed them to conduct operations near developed areas with somewhat diminished environmental analysis obligations. In many cases, the lines between fire hazard reduction, long-term forest health promotion, and short-term MPB response were 
blurred in the application of these authorities. With direction and encouragement by the CBBC and regional and national USFS leaders, planners on individual forest units expedited treatments by planning at larger scales than normal: a single planning document was created for all clearing around recreational infrastructure on a single national forest, and the planning document for clearing power line corridors included all three of the northwest Colorado national forests. As did funding, authorization for expediting these kinds of projects came not through congressional lawmaking but rather through internal agency direction. The emergency approach filtered down to the local ranger district level in which, in some cases, considerations such as design criteria were set aside to expedite treatments and reduce the time spent negotiating details within internal interdisciplinary planning teams. The USFS staff was also reassigned internally within the region to support operations on the ARNF, WRNF, and MBRNF, thereby providing a small but substantial boost in capacity.

One unique aspect of the implementation of the MPB treatments is that it was coordinated largely through the incident command system, the same structure (including a leadership team composed of an incident commander, administrator, public affairs officer, and several specialists) used to manage fast-moving emergencies such as major wildfires, floods, earthquakes, and terrorist attacks (Cosens 2013). This approach was initially suggested by CBBC leadership and embraced by regional USFS officers, one of whom described the MPB epidemic as "a slow-moving wildfire" (Interview \#20). The incident command structure was used to promote efficiency in implementation, develop consistency across multiple forest units, and to communicate a sense of urgency to USFS staff, the broader public, and elected and appointed officials at the national level. It also allowed the incident command team to utilize firefighters that were otherwise unoccupied to work on MPB-related projects. By its very nature, the incident command approach emphasizes short-term action. Interviewees indicated that questions of longer-term forest management or other activities were left to be dealt with outside of this structure.

Various entities, including the $\mathrm{CBBC}$, the Colorado State legislature, rural communities, trade associations, nongovernmental organizations, individuals, and the USFS, made attempts to build capacity to perform needed work by supporting the establishment of new wood-processing infrastructure capable of adding value to trees removed from priority areas. The sudden pulse of wood coming from national forestlands allowed for the establishment of some new facilities and the reopening of previously shuttered mills, but progress on this front was challenged by numerous factors. Most important among these were the onset of an economic recession starting in late 2007 that greatly reduced demand for wood products; the low value of the timber removed (beetle-killed trees begin to crack and decay within a few years after dying), making the window for economic utilization very small, and beetle-killed wood tends to carry a blue stain caused by a beetle-related fungus that can reduce the market value of solid wood products; and specific problems with individual processing facilities, including fires, economic mismanagement, and alleged misuse of federal funds.

According to most interviewees, the one-time funding pulse from the federal government was used effectively to implement the most high-priority projects: hazard trees were removed from thousands of acres around campgrounds, roads, trails, power line corridors, and other critical human infrastructure. The CBBC was not intimately involved in overseeing most project-level planning or implementation; as a regional-scale entity, its primary role was to provide social license for a core program of activities and to advocate for greater funding and use of authorities to expedite treatments. There were exceptions to this pattern, however. As a means of securing continued support for MPB work among the conservation community, the CBBC struck a deal with the three national forests that it would retain veto power over timber sales in which "green" trees (living trees that were not affected by the MPB) were added to salvage sales to make them commercially viable. However, the USFS was not always eager to allow outside entities to shape project-level decisions. The contradictions between the USFS' historic orientation as an independent agency that acts insulated from outside pressure and its contemporary position as a highly networked agency was noted by some members of the CBBC:

\section{I do think all along that tension between the Forest Service's refusal to hand over that discretionary space, that decision space, was always there. It was always a feeling like, where is the accountability? They [the USFS] sit at the table with us, but [they] have to act somehow autonomous (Interview \#12).}

This sentiment reflects the complexity of the USFS' institutional evolution and speaks to the persistence of legacies from earlier eras even as the agency moved toward a more collaborative and networked approach.

\section{The aftermath}

Interviewees agreed that the window of opportunity for aggressive USFS management opened by the MPB epidemic closed very quickly after the outbreak peaked. Once the immediate threat to human life, property, and infrastructure had been mitigated by management activities, the USFS quickly found itself back to the status quo ante both in capacity and in social license. Several interviewees agreed that the elevated funding levels associated with a short-term pulse of money were inadequate to do the kind of long-term and landscape-scale work that would be required to promote landscape resiliency and stimulate economic investments in wood processing infrastructure. The CBBC, having achieved its original objective of delivering funding and authority for the MPB cleanup project, shifted its focus to a fourth value appended to the initial three: the "development of resilient communities within disturbance-driven ecosystems." This was described by some interviewees as having a communications and outreach emphasis designed to educate residents about the reality of forest disturbance dynamics and to support efforts to prepare communities for extreme events. Membership in CBBC dropped off (Fig. 3), and some members openly questioned whether the organization should dissolve entirely. The CBBC shifted direction again in early 2017 to become a regional convening, coordinating, outreach, and education entity for issues related to high-elevation Colorado forests, undergoing a name change in the process.

A number of lasting social and political changes resulted from the MPB epidemic in Colorado, but relatively few were related to formal federal laws, policies, or directives. Some interviewees felt that the MPB epidemic may have helped to further certain policy 
changes related to expanded authorization of the Good Neighbor Authority and to an insect-specific provision added to the 2014 Farm Bill that allowed for expedited planning and treatment within designated insect emergency areas, though these links were not firmly established. The State of Colorado implemented numerous policies and programs designed to influence various aspects of state and private forest management and the wood products industry, and the state Forest Service increased its capacity to work on federal lands via the Good Neighbor Authority. Via the CBBC and other venues, new relationships were forged among stakeholders that had not previously worked together. Further, local USFS units gained greater facility in taking advantage of new contracting, budgeting, and implementation resources such as those noted above. However, in terms of the fundamental questions of USFS capacity, legitimacy, and management approach, interviewees broadly agreed that the MPB event catalyzed relatively little lasting change.

\section{DISCUSSION}

The MPB epidemic in Colorado placed in motion multiple social and political dynamics in response to what was widely perceived as an economic and ecological crisis. Chief among the new patterns of response was the formation of a mixed civil societygovernment organization operating at a regional scale (higher than individual communities or counties but lower than the entire state) whose function was to set broad management priorities and advocate for funding to implement them, along with various other examples of a networked approach to management planning and implementation. However, the ultimate response, as coordinated through the aforementioned governance networks, was largely limited to what can be thought of as "reactive" activities, primarily clearing dead trees from areas of critical human infrastructure and important recreational sites. This is not to say that nothing changed over the course of the roughly 15 years in which the USFS was experiencing or cleaning up from the MPB epidemic. Indeed, local USFS units developed new partnerships, and strengthened existing partnerships, with nonfederal entities for planning and implementation. They used these networks to build agreement for specific projects and advocate for the commitment of national financial resources to local forests, employed emergency response frameworks for overseeing MPB response activities, and utilized new authorities for conducting forest management work. However, these dynamics represent a deepening of the preexisting institutional pathway rather than a new trajectory.

It was necessary for the USFS to secure the consent and enlist the active participation of multiple key stakeholders to move forward with a substantive response to the MPB epidemic. The emergence of the $\mathrm{CBBC}$ as a regional-scale coordinating and consensusbuilding entity broadly matches patterns documented following native beetle epidemics in both British Columbia (Davis and Reed 2013) and southern California (Petersen and Wellstead 2014) and is consistent with the broader institutionalization of place-based collaborative governance within the USFS (Winkel 2014). What made the CBBC's actions in this vein unique was that, from an early point in its evolution, the group was strategizing to enroll state- and national-level agency leaders and elected officials as participants in the governance network and not simply attempting to provide solutions to local-level managers. Thus, the USFS' response to the MPB epidemic was less an autonomous action than it was the response of a network of key stakeholders and agency leaders. At the same time, however, the contours of the response were strongly shaped by the agency's institutional evolution over recent decades.

Three patterns of this evolution are particularly salient in this case. The first is the evolution from agency autonomy to vetocracy (Fukuyama 2014): whereas the USFS was once characterized by its independence from outside interests (Kaufman 1960), Colorado forest units demonstrated the extent to which they came to act within a system full of veto points and veto players. The $\mathrm{CBBC}$, representing many of the most powerful veto players, was an innovation designed to respond to a particular event within a narrowly defined scope of response, focused largely on reducing the institutional barriers to action and increasing financial resources. The second pattern, as McCarthy (2005) observed, is that the USFS has increasingly been characterized by a series of neoliberal reforms that include reduced public funding and the proliferation of a variety of private and civil society innovations that substitute for diminished capacity. The CBBC's fundraising role, along with the widespread use of practices associated with the Good Neighbor Authority, partnerships with utilities, funding by neighborhood groups, and similar arrangements, are evidence of the USFS' dependence on outside resources for its continued functioning. The third pattern is an institutional reorientation of the USFS away from long-term multiple-use management and toward short-term emergency response (with an emphasis on wildfire). In many ways, agency and nonagency actors in Colorado "borrowed" institutions designed for wildfire, principally the incident command structure, and applied them to high priority tree removal projects.

The northwestern Colorado case demonstrates the enduring importance of national-level bureaucratic institutions and regional path dependency, even in the face of widespread innovation and experimentation at more local scales. The fact that so much of the CBBC's effort was put into attempting to navigate existing bureaucratic obstacles to achieve relatively short-term outcomes, combined with our finding of relatively limited longterm changes as a result of the epidemic, the persistent lack of timber processing infrastructure, and the USFS' reversion to the status quo ante once the most pressing human safety and infrastructure concerns had been addressed, suggests strong limitations in the latitude for institutional adaptation by innovative local-scale actors. Given that northwestern Colorado can be considered to be a critical case (Flyvbjerg 2006) for potential institutional adaptation in the face of an environmental shock, the relative absence of lasting change indicates that such national-level institutions are both persistent and powerful. This is not to say that these bureaucratic institutions are static; indeed, they have been undergoing evolutionary change for some time. However, the shock caused by the MPB epidemic under study was accommodated by lower-scale innovation within the existing institutional framework rather than resulting in changes to the framework itself. For example, use of the incident command structure to implement high-priority management activities in the wake of the epidemic represented a novel use of existing institutional resources, but ultimately reinforced the short-term emergency framing of the MPB response. 


\section{CONCLUSIONS}

Understanding the adaptability of the forest governance system in Colorado, as in other geographies in which governmental entities control environmental resources, requires close attention to the institutions that drive and shape management bureaucracies. This is true in spite of the fact that public land governance in the U.S. has transitioned from a relatively selfcontained and autonomous approach to a much more networked approach that relies on various nonfederal actors to supply both the legitimacy and capacity to act, a pattern that mirrors more widespread global trends toward networked governance. Our analysis of this case demonstrates that local and regional actors, operating within a larger-scale institutional framework, can be quite creative and innovative in navigating barriers and responding to broad social pressures for action. However, it also illustrates that their latitude for adaptation is not boundless and that persistent bureaucratic institutions and national and regional path dependence may strongly shape both the scope and content of adaptive behavior. Indeed, the inability of a highly salient environmental shock event to demonstrably modify environmental management institutions in this case underscores the weightiness of those bureaucratic institutions themselves. In this case, overcoming inertia at the national scale was complicated by longterm economic and social dynamics at the regional scale.

Collectively, these findings demonstrate that hierarchy still matters, even in the age of networked governance. Hybrid arrangements that blend networked and hierarchical models may not prove to be adaptive if large, slow-moving variables bound the scope of local action and limit the kinds of actions potentially considered by network actors. In other words, the adaptability of multiscalar institutional frameworks may only be as strong as their most inflexible elements. This finding suggests that adaptation to global change dynamics in general may be more difficult than often recognized because even extreme events may be accommodated by short-term innovations that fail to generate substantial changes in prevailing practices or paradigms.

Responses to this article can be read online at: http://www.ecologyandsociety.org/issues/responses. $\mathrm{php} / 9717$

\section{Acknowledgments:}

The authors sincerely thank our interviewees for sharing their time and perspectives with us. Thank you to Tony Cheng for supplying data on CBBC membership. Thank you to Kelly Jacobson for assistance with Figure 4. This research is based on work supported by the National Science Foundation under grant No. 1414041.

\section{LITERATURE CITED}

Abrams, J., E. J. Davis, and C. Moseley. 2015a. Community-based organizations and institutional work in the remote rural West. Review of Policy Research 32(6):675-698. http://dx.doi. org/10.1111/ropr.12148

Abrams, J. B., M. Knapp, T. B. Paveglio, A. Ellison, C. Moseley, M. Nielsen-Pincus, and M. S. Carroll. 2015b. Re-envisioning community-wildfire relations in the U.S. West as adaptive governance. Ecology and Society 20(3):34. http://dx.doi. org/10.5751/ES-07848-200334

Alexander, S. M., M. Andrachuk, and D. Armitage. 2016. Navigating governance networks for community-based conservation. Frontiers in Ecology and the Environment 14 (3):155-164. http://dx.doi.org/10.1002/fee.1251

Andrews, T. G. 2011. An environmental history of the Kawuneeche Valley and the headwaters of the Colorado River, Rocky Mountain National Park. University of Colorado at Boulder and Rocky Mountain National Park, Boulder, Colorado, USA. [online] URL: http://publiclands.colostate.edu/wp-content/uploads/2014/10/ andrews-k-valley-eh-final-report-oct-6-2011.compressed.pdf

Armitage, D., F. Berkes, A. Dale, E. Kocho-Schellenberg, and E. Patton. 2011. Co-management and the co-production of knowledge: learning to adapt in Canada's Arctic. Global Environmental Change 21(3):995-1004. http://dx.doi.org/10.1016/ j.gloenvcha.2011.04.006

Bartley, T., K. Andersson, P. Jagger, and F. Van Laerhoven. 2008. The contribution of institutional theories to explaining decentralization of natural resource governance. Society and Natural Resources 21(2):160-174. http://dx.doi.org/10.1080/08941920701617973

Basurto, X. 2005. How locally designed access and use controls can prevent the tragedy of the commons in a Mexican small-scale fishing community. Society and Natural Resources 18(7):643-659. http://dx.doi.org/10.1080/08941920590959631

Beier, C. M., A. L. Lovecraft, and F. S. Chapin, III. 2009. Growth and collapse of a resource system: an adaptive cycle of change in public lands governance and forest management in Alaska. Ecology and Society 14(2):5. http://dx.doi.org/10.5751/ES-02955-140205

Berkes, F. 2012. Sacred ecology. Taylor and Francis, Hoboken, New Jersey, USA.

Berkes, F., J. Colding, and C. Folke. 2003. Navigating socialecological systems: building resilience for complexity and change. Cambridge University Press, Cambridge, UK. http://dx.doi. org/10.1017/CBO9780511541957

Berkes, F., C. Folke, and J. Colding. 1998. Linking social and ecological systems: management practices and social mechanisms for building resilience. Cambridge University Press, Cambridge, UK.

Bettini, Y., R. R. Brown, and F. J. de Haan. 2015. Exploring institutional adaptive capacity in practice: examining water governance adaptation in Australia. Ecology and Society 20(1):47. http://dx.doi.org/10.5751/ES-07291-200147

Birkland, T. A. 2006. Lessons of disaster: policy change after catastrophic events. Georgetown University Press, Washington, D.C., USA.

Birkmann, J., P. Buckle, J. Jaeger, M. Pelling, N. Setiadi, M. Garschagen, N. Fernando, and J. Kropp. 2010. Extreme events and disasters: a window of opportunity for change? Analysis of organizational, institutional and political changes, formal and informal responses after mega-disasters. Natural Hazards 55 (3):637-655. http://dx.doi.org/10.1007/s11069-008-9319-2 
Boin, A., A. McConnell, and P. 't Hart. 2008. Governing after crisis: the politics of investigation, accountability and learning. Cambridge University Press, Cambridge, UK. http://dx.doi. org/10.1017/CBO9780511756122

Chaffin, B. C., H. Gosnell, and B. A. Cosens. 2014. A decade of adaptive governance scholarship: synthesis and future directions. Ecology and Society 19(3):56. http://dx.doi.org/10.5751/ ES-06824-190356

Cheng, A. S., C. Danks, and S. R. Allred. 2011. The role of social and policy learning in changing forest governance: an examination of community-based forestry initiatives in the U.S. Forest Policy and Economics 13(2):89-96. http://dx.doi. org/10.1016/j.forpol.2010.09.005

Cleaver, F. 2002. Reinventing institutions: bricolage and the social embeddedness of natural resource management. European Journal of Development Research 14(2):11-30.

Colorado State Forest Service (CSFS). 2017. 2016 report on the health of Colorado's forests: fire and water. Colorado State University, Fort Collins, Colorado, USA. [online] URL: https:// csfs.colostate.edu/media/sites/22/2017/02/CSU 304464_ForestReport-2016www.pdf

Cosens, B. A. 2013. Legitimacy, adaptation, and resilience in ecosystem management. Ecology and Society 18(1):3. http://dx. doi.org/10.5751/ES-05093-180103

Cumming, G. S., P. Olsson, F. S. Chapin, III, and C. S. Holling. 2013. Resilience, experimentation, and scale mismatches in socialecological landscapes. Landscape Ecology 28(6):1139-1150. http://dx.doi.org/10.1007/s10980-012-9725-4

Davis, E. J., and M. G. Reed. 2013. Multi-level governance of British Columbia's mountain pine beetle crisis: the roles of memory and identity. Geoforum 47:32-41. http://dx.doi. org/10.1016/j.geoforum.2013.02.005

Djalante, R., C. Holley, and F. Thomalla. 2011. Adaptive governance and managing resilience to natural hazards. International Journal of Disaster Risk Science 2(4):1-14. http://dx. doi.org/10.1007/s13753-011-0015-6

Dowsley, M. 2008. Developing multi-level institutions from topdown ancestors. International Journal of the Commons 2(1):55-74. http://dx.doi.org/10.18352/ijc.62

Dressler, W., B. Büscher, M. Schoon, D. Brockington, T. Hayes, C. A. Kull, J. McCarthy, and K. Shrestha. 2010. From hope to crisis and back again? A critical history of the global CBNRM narrative. Environmental Conservation 37(1):5-15. http://dx.doi. org/10.1017/S0376892910000044

Flint, C. G., B. McFarlane, and M. Müller. 2009. Human dimensions of forest disturbance by insects: an international synthesis. Environmental Management 43(6):1174-1186. http://dx. doi.org/10.1007/s00267-008-9193-4

Flyvbjerg, B. 2006. Five misunderstandings about case-study research. Qualitative Inquiry 12(2):219-245. http://dx.doi. org/10.1177/1077800405284363

Folke, C., T. Hahn, P. Olsson, and J. Norberg. 2005. Adaptive governance of social-ecological systems. Annual Review of
Environment and Resources 30:441-473. http://dx.doi.org/10.1146/ annurev.energy.30.050504.144511

Fukuyama, F. 2014. Political order and political decay: from the Industrial Revolution to the globalization of democracy. Farrar, Straus, and Giroux, New York, New York, USA.

Furniss, M. M. 2007. A history of forest entomology in the Intermountain and Rocky Mountain areas, 1901 to 1982. General technical report. U.S. Department of Agriculture, Forest Service, Rocky Mountain Research Station, Fort Collins, Colorado, USA.

Garmestani, A. S., and M. H. Benson. 2013. A framework for resilience-based governance of social-ecological systems. Ecology and Society 18(1):9. http://dx.doi.org/10.5751/ES-05180-180109

Grummon, C. A. 2016. Examining the role of collaborative governance in fostering adaptive capacity: a case study from northwest Colorado. Thesis. University of Oregon, Eugene, Oregon, USA. [online] URL: https://scholarsbank.uoregon.edu/ xmlui/handle/1794/20516

Gunderson, L. H., C. S. Holling, and S. S. Light, editors. 1995. Barriers and bridges to the renewal of ecosystems and institutions. Columbia University Press, New York, New York, USA.

Holling, C. S., and G. K. Meffe. 1996. Command and control and the pathology of natural resource management. Conservation Biology 10(2):328-337. http://dx.doi.org/10.1046/

j.1523-1739.1996.10020328.x

Kaufman, H. 1960. The forest ranger: a study in administrative behavior. Johns Hopkins Press, Baltimore, Maryland, USA.

Keast, R. L., M. Mandell, and K. A. Brown. 2006. Mixing state, market and network governance modes: the role of government in "crowded" policy domains. International Journal of Organization Theory and Behavior 9(1):27. [online] URL: http:// epubs.scu.edu.au/bus_pubs/765/

Klooster, D. J. 2002. Toward adaptive community forest management: integrating local forest knowledge with scientific forestry. Economic Geography 78(1):43-70. http://dx.doi. org/10.2307/4140823

Koontz, T. M., D. Gupta, P. Mudliar, and P. Ranjan. 2015. Adaptive institutions in social-ecological systems governance: a synthesis framework. Environmental Science and Policy 53:139-151. http://dx.doi.org/10.1016/j.envsci.2015.01.003

Le Master, D. C. 1984. Decade of change: the remaking of Forest Service statutory authority during the 1970s. Greenwood, Westport, Connecticut, USA.

Lebel, L., J. M. Anderies, B. Campbell, C. Folke, S. HatfieldDodds, T. P. Hughes, and J. Wilson. 2006. Governance and the capacity to manage resilience in regional social-ecological systems. Ecology and Society 11(1):19. http://dx.doi.org/10.5751/ ES-01606-110119

Mahoney, J., and K. Thelen, editors. 2010. Explaining institutional change: ambiguity, agency, and power. Cambridge University Press, Cambridge, UK. http://dx.doi.org/10.1017/CBO9780511806414

McCarthy, J. 2005. Devolution in the woods: community forestry as hybrid neoliberalism. Environment and Planning A 37 (6):995-1014. http://dx.doi.org/10.1068/a36266 
Mitton, J. B., and S. M. Ferrenberg. 2012. Mountain pine beetle develops an unprecedented summer generation in response to climate warming. American Naturalist 179(5):E163-E171. http:// dx.doi.org/10.1086/665007

Mockrin, M. H., S. I. Stewart, V. C. Radeloff, and R. B. Hammer. 2016. Recovery and adaptation after wildfire on the Colorado Front Range (2010-12). International Journal of Wildland Fire 25 (11):1144-1155. http://dx.doi.org/10.1071/WF16020

Morris, J. L., S. Cottrell, C. J. Fettig, W. D. Hansen, R. L. Sherriff, V. A. Carter, J. L. Clear, J. Clement, R. J. DeRose, J. A. Hicke, P. E. Higuera, K. M. Mattor, A. W. R. Seddon, H. T. Seppä, J. D. Stednick, and S. J. Seybold. 2017. Managing bark beetle impacts on ecosystems and society: priority questions to motivate future research. Journal of Applied Ecology 54(3):750-760. http://dx.doi. org/10.1111/1365-2664.12782

Müller, M. 2011. How natural disturbance triggers political conflict: bark beetles and the meaning of landscape in the Bavarian Forest. Global Environmental Change 21(3):935-946. http://dx.doi.org/10.1016/j.gloenvcha.2011.05.004

Naess, L. O., G. Bang, S. Eriksen, and J. Vevatne. 2005. Institutional adaptation to climate change: flood responses at the municipal level in Norway. Global Environmental Change 15 (2):125-138. http://dx.doi.org/10.1016/j.gloenvcha.2004.10.003

Nelson, H. 2007. Does a crisis matter? Forest policy responses to the mountain pine beetle epidemic in British Columbia. Canadian Journal of Agricultural Economics 55(4):459-470. http://dx.doi. org/10.1111/j.1744-7976.2007.00102.X

Newig, J., D. Günther, and C. Pahl-Wostl. 2010. Synapses in the network: learning in governance networks in the context of environmental management. Ecology and Society 15(4):24. http:// dx.doi.org/10.5751/ES-03713-150424

Nohrstedt, D., and C. M. Weible. 2010. The logic of policy change after crisis: proximity and subsystem interaction. Risk, Hazards and Crisis in Public Policy 1(2):1-32. http://dx.doi. org/10.2202/1944-4079.1035

North, D. C. 1990. Institutions, institutional change and economic performance. Cambridge University Press, Cambridge, UK. http://dx.doi.org/10.1017/CBO9780511808678

Ostrom, E. 1990. Governing the commons: the evolution of institutions for collective action. Cambridge University Press, Cambridge, UK.

Ostrom, E. 2001. Decentralization and development: the new panacea. Pages 237-256 in K. Dowding, J. Hughes, and $\mathrm{H}$. Margetts, editors. Challenges to democracy. Palgrave Macmillan, Basingstoke, UK. http://dx.doi.org/10.1057/9780230502185_15

Ostrom, E. 2005. Understanding institutional diversity. Princeton University Press, Princeton, New Jersey, USA.

Paton, D., and F. Tedim, editors. 2012. Wildfire and community: facilitating preparedness and resilience. Charles C. Thomas, Springfield, Illinois, USA.

Petersen, B., and D. Stuart. 2014. Explanations of a changing landscape: a critical examination of the British Columbia bark beetle epidemic. Environment and Planning A 46(3):598-613. http://dx.doi.org/10.1068/a4672
Petersen, B., and A. M. Wellstead. 2014. Responding to forest catastrophe in the face of unprecedented forest challenges: the emergence of new governance arrangements. ISRN Economics 2014:982481. http://dx.doi.org/10.1155/2014/982481

Plummer, R., J. Velaniškis, D. de Grosbois, R. D. Kreutzwiser, and R. de Loë. 2010. The development of new environmental policies and processes in response to a crisis: the case of the multiple barrier approach for safe drinking water. Environmental Science and Policy 13(6):535-548. http://dx.doi.org/10.1016/j. envsci.2010.05.004

Raffa, K. F., B. H. Aukema, B. J. Bentz, A. L. Carroll, J. A. Hicke, M. G. Turner, and W. H. Romme. 2008. Cross-scale drivers of natural disturbances prone to anthropogenic amplification: the dynamics of bark beetle eruptions. Bioscience 58(6):501-517. http://dx.doi.org/10.1641/B580607

Scarlett, L., and M. McKinney. 2016. Connecting people and places: the emerging role of network governance in large landscape conservation. Frontiers in Ecology and the Environment 14(3):116-125. http://dx.doi.org/10.1002/fee.1247

Scott, W. R. 2014. Institutions and organizations: ideas, interests, and identities. Fourth edition. Sage, Thousand Oaks, California, USA.

Shinn, J. E. 2016. Adaptive environmental governance of changing social-ecological systems: empirical insights from the Okavango Delta, Botswana. Global Environmental Change 40:50-59. http://dx.doi.org/10.1016/j.gloenvcha.2016.06.011

Smit, B., and J. Wandel. 2006. Adaptation, adaptive capacity and vulnerability. Global Environmental Change 16(3):282-292. http:// dx.doi.org/10.1016/j.gloenvcha.2006.03.008

Smith, W. B., P. D. Miles, C. H. Perry, and S. A. Pugh. 2009. Forest resources of the United States, 2007: a technical document supporting the forest service 2010 RPA Assessment. USDA Forest Service, Washington, D.C., USA. [online] URL: https://www.fs. fed.us/nrs/pubs/gtr/gtr wo78.pdf

Solecki, W. D., and S. Michaels. 1994. Looking through the postdisaster policy window. Environmental Management 18 (4):587-595. http://dx.doi.org/10.1007/BF02400861

Steelman, T. A., and C. A. Burke. 2007. Is wildfire policy in the United States sustainable? Journal of Forestry 105(2):67-72. http://dx.doi.org/10.2139/ssrn.1931057

Strauss, A. L., and J. M. Corbin. 1998. Basics of qualitative research: techniques and procedures for developing grounded theory. Sage, Thousand Oaks, California, USA.

Streeck, W., and K. A. Thelen. 2005. Beyond continuity: institutional change in advanced political economies. Oxford University Press, Oxford, UK.

Wilson, R. K. 2014. America's public lands: from Yellowstone to Smokey Bear and beyond. Rowman and Littlefield, Lanham, Maryland, USA.

Winkel, G. 2014. When the pendulum doesn't find its center: environmental narratives, strategies, and forest policy change in the U.S. Pacific Northwest. Global Environmental Change 27:84-95. http://dx.doi.org/10.1016/j.gloenvcha.2014.04.009 
Wyborn, C., L. Yung, D. Murphy, and D. R. Williams. 2015. Situating adaptation: how governance challenges and perceptions of uncertainty influence adaptation in the Rocky Mountains. Regional Environmental Change 15(4):669-682. http://dx.doi. org/10.1007/s10113-014-0663-3

Yin, R. K. 2003. Case study research: design and methods. Sage, Thousand Oaks, California, USA.

Young, O. R. 2002a. The institutional dimensions of environmental change: fit, interplay, and scale. MIT Press, Cambridge, Massachusetts, USA.

Young, O. R. 2002b. Institutional interplay: the environmental consequences of cross-scale interactions. Pages 263-291 in E. Ostrom, T. Dietz, N. Dolsak, P. C. Stern, S. Stonich, and E. U. Weber, editors. The drama of the commons. National Academy, Washington, D.C., USA.

Young, O. R. 2010. Institutional dynamics: resilience, vulnerability and adaptation in environmental and resource regimes. Global Environmental Change 20(3):378-385. http://dx. doi.org/10.1016/j.gloenvcha.2009.10.001 